\title{
Polysèmes
}

Revue d'études intertextuelles et intermédiales

\section{Bruce Nauman and the Time on One's Hands: Control, Anxiety and the Desire for Endlessness in Early Video Art}

Bruce Nauman et le temps devant soi : contrôle, anxiété et désir d'infinitude dans les premières œuvres d'art vidéo

\section{Patrick Van Rossem}

\section{OpenEdition}

\section{Journals}

\section{Electronic version}

URL: http://journals.openedition.org/polysemes/1947

DOI: $10.4000 /$ polysemes. 1947

ISSN: 2496-4212

Publisher

SAIT

\section{Electronic reference}

Patrick Van Rossem, « Bruce Nauman and the Time on One's Hands: Control, Anxiety and the Desire for Endlessness in Early Video Art », Polysèmes [Online], 17 | 2017, Online since 30 April 2017, connection on 17 June 2020. URL : http://journals.openedition.org/polysemes/1947 ; DOI : https:// doi.org/10.4000/polysemes.1947

This text was automatically generated on 17 June 2020 .

Polysèmes 


\title{
Bruce Nauman and the Time on One's Hands: Control, Anxiety and the Desire for Endlessness in Early Video Art
}

\author{
Bruce Nauman et le temps devant soi : contrôle, anxiété et désir d'infinitude \\ dans les premières œuvres d'art vidéo
}

Patrick Van Rossem

"I would prefer that it went on forever"1

\section{Stamping in the Studio}

1 In the video recorded performance Stamping in the Studio (1968), American artist Bruce Nauman (Fort Wayne, Indiana, 1941) is seen running around while stamping his feet. ${ }^{2}$ The stamping is performed for sixty minutes; the duration of the videotape reel. When screened - the videotape has to be screened on a monitor - it is also played as a loop, thus evoking a sense of endlessness. The artist also videotaped himself from an inverted camera position. He hung the video camera upside down while videotaping himself from a high vantage point. This abstracts the image. It also disturbs the viewers' visual perception and ocular habits. It does not however imply that there is a decreased proximity between viewer and performer. Even the screen presence of the performance does not temper the impact of the actions upon the audience, for the screen is "ruptured" by the pounding echoes that escape from the artist's feet. These sounds fill the empty space of the studio and envelop the audience watching and listening in the museum or gallery. They fade away, are overturned by new encounters between feet and floor, and so on. Their intensity varies and the speed of the stamping fluctuates. It is never constant and always slightly different from the previous rhythmic chord. Bruce Nauman has made videotaped performances where the sound and the image are out of sync. ${ }^{3}$ In Stamping in the Studio however they are not. The sound always follows the motion of his feet. The 
locomotion of the artist's footsteps also changes only gradually and there are only a few ruptures in the flux of movement. Nauman obviously controls his pace and physical effort. He slows down, relaxes, moves quicker. At times he seems exhausted, then again forceful, but always determined to go on. Even when the artist disappears, when he moves away from the camera eye, we can still hear the pounding of his feet. The videotaped performance goes on with the same determination; the artist shows an almost obsessive desire to go on and to be present and in control of his steps.

How can we understand this rather strange repetitive action? The artist appears as a caged "animal", a victim of solitude, a madman running in circles. The performance evokes anxiety, solitude and absurdity, but also irony and even slapstick. Was Nauman debunking the myth of the studio; a space considered almost sacred, a witness to countless acts of artistic genius? ${ }^{4}$ Or, was the artist merely using his body, physical movement and sound in a minimalistic way; as artistic tools in order to create feelings and impressions of alienation, estrangement, absurdity and so on? And why did he want the performance to go on forever? Before we engage with these questions we have to create a meaningful context for our analysis. First we will provide some historical information as to the rise and early artistic use of video. We will outline some of the influences Nauman spoke of regarding his videotaped performances. After this, we will consider the so-called performative turn. The "turn" started around the end of the 1950s and it is characterized amongst others by a heightened awareness among visual artists of the presence of the audience. We hope to show that Nauman's choice for the time-based medium video was partly triggered by this awareness. We will further argue that the characteristics of Stamping in the Studio - the repetitive action, the anxiety and the sense of determination that are evoked, as well as the control exercised by Nauman - also seem to come from the heightened awareness of having an audience, of having, as Nauman once stated, an anonymous audience.

\section{Experimental times}

3 Working with video became possible when in 1965 Sony Corporation launched the first portable video camera, the so-called Sony Portapak (Spielmann 75-77). This new, quite inexpensive and user-friendly technology, quickly found its way into artists' hands. Even the rather poor, "milky" character of the video images did not temper artistic fascination. The reasons for this artistic interest in open-reel video are of course varied. The fact that video introduced the possibility to work with an unorthodox art material, that it provided the opportunity to oppose traditional art materials and established but also heavily burdened disciplines such as sculpture and painting is of course a major impetus for its use. The 1960s and seventies were experimental decades wherein artists sought to defy traditional classifications of the arts and started to be preoccupied by the so-called dematerialization of the art object, both opposing easy marketability and the visual arts' long-term preoccupation with space and matter. ${ }^{5}$ The fact that videotapes could be reproduced also subverted typical modernist criteria such as uniqueness and authenticity. Uniqueness was troubled by the simple fact that more copies existed of the same work. Authenticity was endangered by the lack of the artist's physical touch, the absence of an indexical imprint and the fact that the performances could in theory easily be repeated and videotaped by others. Video also offered a more contemporaneous link with a Western culture that became increasingly preoccupied with cinematic and video 
images, both in television and cinema. But one of the reasons artists chose video is surely the fact that it offered the possibility to work with and also "mold" time and to make duration and instances of time more tangible. Visual artists never before have had such straightforward temporal instruments at their disposal. American artists such as Vito Acconci (b. 1940), Dan Graham (b. 1942), Richard Serra (b. 1939), Nam June Paik (1932 South Korea-2006), Bill Viola (b. 1951) and many more started experimenting with video's temporal and visual qualities: they discovered playback and looping, warped images with magnets; they delayed and speeded up the image flow, synchronized and desynchronized sound and image in order to segment and subvert visual and temporal continuity; they also engaged viewers over time in large video installations.

One of the pioneers that used the Portapak in order to explore amongst others a heightened awareness of having time, of having to do something with the time on one's hands, was American artist Bruce Nauman. ${ }^{6}$ In 1968 and 1969, he experimented with time and process by recording several simple physical actions such as running, pacing, balancing, throwing and catching a ball, manipulating a fluorescent tube, repetitively playing a note on a violin, falling into a corner and so on. The motivation for recording these simple, repetitive actions came from a logic that echoes a "Duchampian" strategy. Nauman has stated:

If you see yourself as an artist and you function in a studio and you are not a painter, if you don't start out with some canvas, you do all kinds of things - you sit in a chair or pace around. And then the question goes back to what is art? And art is what an artist does, just sitting around in his studio. (Nauman qtd in van Bruggen 14)

And

[...] this in turn raises the fundamental question of what an artist does when left alone in the studio. My conclusion was that I was an artist and I was in the studio, then whatever I was doing in the studio must be art. (Nauman qtd in Wallace and Keziere 18)

Alone in his studio, Bruce Nauman discovered himself - or better the activities he was engaged in - to be a valid medium for his art. He and his behavior became a sort of found object, a readymade presence that could be given the status of art. But the activities were of course far from being randomly chosen. In fact, upon a closer look, it is feasible to say that all the activities can be related to certain tropes associated with the creative act. Pacing can be seen as a metaphor for thinking, but also for doubt and insecurity. Leaning against the wall can again be related to thinking, but also for instance to contemplating, resting... Walking on the perimeters of a square can be interpreted as a metaphor for exploration, carefulness and attentiveness. Bouncing balls in turn can be seen as a metaphor for a more lively and all consuming creative act. Playing a note on the violin, while not knowing how to play the violin, as was the case with Nauman, can be related to the exploration of a new artistic medium or discipline. It functions as a metaphor for an artist's search for new artistic paths. It can also be associated with amateurism and thus be seen as a comment on the bond between the studio and creative genius and professionalism. The manipulation of a fluorescent tube could well be interpreted as a metaphor for the entire set of works wherein Nauman took up aspects of the creative act (thinking, producing something via an activity, exploring, carefulness, attentiveness, doubt, hesitation, effort, going through one's insecurity...) for it is the manipulation of something immaterial turned into something more material and concrete. Light of course 
can also be understood as a metaphor for "inspiration". Again it can be related to the inspiration Nauman got from his activities, ideas and feelings in the studio.

But activities develop over time. The latter was of great interest to the artist and probably also one of the major reasons why he and many other artists opted for time-based media:

And so I really liked that idea of performance or videotape that went on longer than film, or film that went on in loops and things like that - you could walk in at any point. I think I like - there's a kind of tension set up when you... A lot of films were about dance or exercise problems or repeated movements, as were the performances. You have the repeated action, and at the same time, over a longer period of time you have mistakes or at least a chance, changes and you get tired and all kinds of things happen, so there's a certain tension that you can exploit once you begin to understand how these things function. ${ }^{7}$

The idea of change, building up tension, activity, process and the occurrence of accidental "mistakes" can also be related to the act of creating something. This of course can easily be situated in relation to the setting of the performances: the studio. The latter is the site where artists make works that are the product of a process in which they are engaged over time with their physical, emotional, rational and sensible existence. Seeking new ways to engage with his own desire to produce art brought the artist to an elaboration and performative "translation" - understood here as a staged repetitive action - of just these aspects that inform the creative act. Taken together, Nauman seemed to make up art - as is suggested by the video Art Make Up, wherein the artist literally rubbed make-up all over his upper body and face, turning himself into a kind of "body-canvas" or pictorial body - due to the absence of pictorial and sculptural possibilities. ${ }^{8}$ But the search appears both alienating, bereaved and sometimes anxious and absurd. The videos then could well be understood as "testimonies" of a transitional period, wherein artists no longer took for granted both sculpture and painting and had to seek out new ways to embody their thoughts and feelings. The artist stated: "It seems to me that painting is not going to get us anywhere, and most sculpture is not going to either, and art has to go somewhere". ${ }^{9}$ Finding new ways of artistic embodiment resulted in Nauman looking at the very core of artistic creation: his own body, the physical activity of making art and the emotions and desires that inform it.

The performances were also stimulated by Nauman's frequent contacts with other artists, performers and musicians. He was also inspired by a number of people who experimented with time in their work. Bearing in mind Stamping in the Studio, it comes as no surprise that Nauman mentioned amongst others composers Karlheinz Stockhausen (1928-2007), Steve Reich (b. 1936), Terry Riley (b. 1935) and La Monte Young (b. 1935), writer and theatre director Samuel Beckett (1906-1989), dancer-choreographer Meredith Monk (b. 1942) and so on. In Stockhausen's composition Zeitmasse (1956-1957), Nauman found inspiration in the interplay between metronomic and relative tempi and in the alternations of fast and slow musical passages (van Bruggen 231). Beckett drew his attention to the fact that simple actions, such as Molloy passing stones from one pocket to another, can acquire great resonance when subjected to repetition (van Bruggen 18). No matter how limited, strange or pointless actions such as walking, running, falling and so on, may seem, Nauman considered them all worthy subjects for careful examination. The idea that a simple and daily action could become a protagonist in a dance was something he learned from Merce Cunningham (1919-2009)..$^{10}$ Stamping in the Studio was in fact characterized by him as a kind of dance or exercise. ${ }^{11}$ But he was no dancer, in fact he was a dilettante when it came to dance. Meredith Monk however, whom he met in the 
summer of 1969, made clear to him that dilettantism and amateurism, she herself working with untrained dancers, were indeed adequate for the exploration of body awareness and other issues Nauman was pursuing at the time. ${ }^{12}$

In that same year Nauman also met Steve Reich and Terry Wiley. He observed the composers while they were rehearsing and planning the piece Overevident Falls, a piece that bears a lot of resemblance to Reich's Pendulum Music (van Bruggen 12). The focus upon sound, the repetition and locomotion involved in creating it, but above all the sculptural quality sound acquired in these pieces must have caught Nauman's ear. It obviously fed into his interest in a multisensory aesthetic as well as in his skeptical attitude towards the ocular. Finally, the music performances of La Monte Young inspired Nauman because of the ongoing nature of the performances. Nauman especially liked the idea that there was no beginning nor end to the performance of his music and that it disrupted storytelling and narrative altogether. ${ }^{13}$ One can easily relate these ideas to the performance Stamping in the Studio.

It is clear that Nauman was part of a cultural and artistic climate that favored time-based arts and experimented with repetition in order to subvert traditional aesthetics but also and foremost to create new embodied impressions through multi-sensorial experiments. The experiences Nauman aimed for were however not minimalistic impressions of continuity and discontinuity, nor were they self-consciousness, bodily awareness or confusion on the part of the audience. Even boredom, a feeling researched by many of the artists and composers that inspired him, was not an important, or even ultimate goal. He stated:

[...] I liked the idea that you could arrive someplace and go to lunch and come back and it would still be going on. In a sense you knew what was going on and you could understand the whole thing. [...] It might even be boring, but if you know it is going to be a half hour you can handle that because you know that there's not going to be a plot or a structure you will have to get through. (Morgan 266)

11 Simplicity and repetition were favored by Nauman because they could easily be grasped by the audience. It also meant that watching the whole performance was unnecessary, because the progression of the action was subordinated to a continuous control that kept it delimitated, clear and rather uniform. This is fascinating, for repetition and duration are introduced here in order to make sure that the audience knows, understands and experiences appropriately what is presented. The issue was indeed very much on Nauman's mind at the time: “[...] I mistrust audience participation. That is why I try to make these works as limiting as possible. It has more to do with me not allowing people to make their own performance out of my art". ${ }^{14}$ And: "There was a period once when I did a number of performance pieces with videotape; they required what I guess you could call sets. They were used to control the content, and became important. [...] If you can limit the kinds of things which can be performed then I can control part of the experience" (Wallace and Keziere 8).

12 The delimitation of the action, the control exercised over it, the choice for showing the video as a continuous loop and the durational character of it formed by a repetitive action all seem to point in the direction of semantic and experiential control. The tension that arises from the activity is therefore almost a testimony of Nauman's worries about the experiences his work would evoke. "There's a certain tension that you can exploit once you begin to understand how these things function" ${ }^{15}$, he said. He also stated that "the tension is intentional" (Wallace and Keziere 10). Why, may we ask, was Nauman 
trying to almost literally stamp ideas and experiences in the minds and bodies of his audience? Why was "proper" understanding and adequate experiencing important rather than lexical and interpretative freedom? In order to answer this question we will consider the performative turn in the visual arts and look at why Nauman and some of his contemporaries reacted to the presence of the audience.

\section{The performative turn: having an audience}

Already at the end of the 1980s, Henry Sayre wrote in his acclaimed book The Object of Performance that by the beginning of the seventies, "the site of presence in art had shifted from art's object to art's audience, from the textual or plastic to the experiential" (Sayre 5). The shift implies that we can no longer merely consider the work of art as an imminent, self-referential and self-contained symbolical whole. Art often favors screenbased work, process and time, staging, the particularity of a site, the exploration of social and inter-human relations, interactivity, the event. It is consciously aware of the presence of the audience, it enacts and re-enacts and it favors instability and multiplicity of meaning. Sayre's observation has recently been joined by other theoretical considerations wherein art histories' lack of interest in the performative is criticized. They propose alternative routes for the study of art by looking at models developed in theatre and performance studies.

The shift from the textual and plastic to the experiential has for instance been characterized by Erika Fischer-Lichte as a performative turn. It implies that our culture no longer creates its self-image and self-understanding through texts and artifacts, but via "cultural performances". According to Fischer-Lichte, Western culture has made the transition from a text-based culture to a predominant performative culture. The transition has been firmly influenced by the rise of electronic media and new-media technologies and the arts have not remained unaffected. Fischer-Lichte remarks that the artistic preference for performance is already noticeable at the end of the 1950s and the beginning of the 1960s. Art that somehow favours performance-like aspects can be found in action painting, body art, land art, in light sculptures, video-installations and in performance art itself. Again, the artist becomes a performer. He or she stands before an audience or invites the audience to move around or interact with exhibited things (Fischer-Lichte 3). ${ }^{16}$

15 This evolution, Fischer-Lichte remarks, clearly suggests that we take theatre - because of its intense preoccupation with performativity - as a model for the analyses and study of the visual arts. Notions such as scenography, masquerade, spectacle, body, but also the interaction with the audience... have all been thoroughly theorized in theatre studies and can be activated in our understanding of the omnipresent evolution from "text-Modell zum performance-Modell" (Fischer-Lichte 23). It should be noted however that FischerLichte does not consider the transformation to be a breach. She proposes, rather, to come to a model wherein the textual approach (considering the work of art as a complex of representational and referential signs) and the performative approach (considering the work of art as something that is actively directed towards the public's mental, emotional, sensorial and physical experience) co-exist. Dorothea von Hantelmann has made a similar analysis in her consideration of the performative turn in art. She points to the importance of considering the interrelation between presence and representation as an essential feature of a work's symbolical existence. The performative must be understood 
as a dramaturgic concept, that realizes itself both in the act of creation and in the experience of the artwork by the audience. Attributing meaning is always procedural - an event -, that also realizes itself in the perception of the audience. The latter however is often overlooked by Art History. The discipline often historicizes, and according to the author, also mortifies art rather than understand it within actual perception. ${ }^{17}$

Both Fischer-Lichte and von Hantelmann rightfully point to a lack in art historical research. The blindness for the presence of the audience, for its perception, sensorial and physical experience and its interpretive act is without a doubt an important blind spot in the disciplines' focus. Meaning is always the outcome of an interplay between a work's aesthetic and artistic identity created by the artist, and the interpretive act of the audience. Humans and audiences change over time. So do ways of seeing and thus also meanings. But the performative turn also implies - as suggested by Henry Sayre - that artists have become more and more aware of the fact that there is an audience present. Sayre victoriously wrote: "The shift in the accepted site of presence [...], from object to audience, has had profound effects on art generally. It has opened art to the plurality of interpretation" (Sayre 6). There is of course much to be said in favor of the explicit search for semantic multiplicity. But art not always behaves as critics think or as they would like. Indeed, looking at some works of Nauman will make it clear that a more performative-oriented approach does not always bring about a considerable interpretive plurality. Neither does the shift from object to audience automatically imply a decrease of authorial presence or the desire to communicate and represent in an intentional way.

In our view on things, we feel that one should never stop being intrigued by the fact that by the end of the 1960s and the beginning of the 1970s artists seemed to be so impregnated by the presence of an active audience (a museum- and gallery-going audience that consciously decides that it wants to see art, actively seeks art and also longs for "something" in art) that they came to "abolish" the work of art as an "intermediate" between themselves and the audience. American artist Dan Graham ( $\left.{ }^{\circ} 1942\right)$ said: "The performances were based on the present-time consciousness of the artist (who in the performances was temporarily replacing the art object) and the spectator's present-time perceptions" (Graham 142). Performance artist Vito Acconci ( $\left.{ }^{\circ} 1940\right)$ also phrased it poignantly:

Assume a general condition of art-experiencing: viewer, entering exhibition area, orients himself/herself to artwork as if toward target - viewer aims in on artwork. This target-making, then, can be used beforehand, as a condition of art doing: I can aim in on myself, treat myself as target - my activity of target-making, then, can be treated as a target by viewers. (Acconci 358)

18 The idea of the target is of course not new to art. American artist Jasper Johns (b. 1930) experimented with it in his work for a number of years. The target became a figure with which Johns "targeted" expressionistic idioms of painting. His famous work Target with Plaster Casts literally carries in its confines the remains of a pictorial body "shot" to pieces and buried in small "coffins". With it, Johns also reformulated art - in the most explicit way possible - in terms of semantic multiplicity. ${ }^{18}$ The arbitrariness of the signs, and the interplay between them, triggers readings that are more open-ended and polyphonic. Johns strengthened his point with the work Do it yourself (Target) (1960). Under a blank drawn target, Johns fixed a paintbrush and three dry watercolor cakes. He subsequently signed the work with his name, but added "AND" with a blank space after it, thus inviting the audience to complete and sign the work. The proposition is clear. Johns toned down 
his own authorship and acknowledged the existence of an interpretive and thus coauthoring audience. The latter got the lexical freedom Johns wanted art to be about.

But the legacy proved to be a charged one. For from the empty spaces of the casts sprang a body that manifested itself with force in the perception of the audience. We argue that the videotaped performances of Bruce Nauman, but also those of Vito Acconci and Dan Graham, reveal the troublesome encounter of these artists with the audience. Their appearance in these works and the relation between the artist and audience it highlights point to a creative instance that has not yet come to terms with the presence of an interpretive other. The introduction of a form of self-presentation seems to point to a need to position oneself as a creative instance; to show the artist-author behind the work. The pivotal figure in our analysis is of course Bruce Nauman, for it is in his oeuvre that the communication and representation debacle is best embodied. We argue that his choice for a more performative mode of making art was in part also a strategy to obtain a more direct and more measured impact on the audience. It highlights more than anything the intense preoccupation of this artist with the presence of the audience and his desire to control the experience and interpretation of his art. The time on his hands, the time he got from not knowing how to proceed as an artist now that painting and sculpture were no longer possible, was filled and taken up by the presence of an unknown figure - the viewer - that for the first time in the history of the visual arts proved hard to deal with. Nauman called for his or her attention.

\section{Bruce Nauman: not just any audience}

PLEASE PAY ATTENTION PLEASE (1973) are the letraset words mounted by Bruce Nauman on a fragile cellophane support. ${ }^{19}$ The words, written in bold black letters, seem to strive for a perlocutionary effort: the audience paying attention. But to what, one might ask, do we have to pay attention? To the fact that we are not paying enough attention, be it willingly or unwillingly? Again, Nauman makes clear why paying attention was so important for him: "I didn't want to present situations where people could have too much freedom to invent what they thought was going on [...] I wanted it to be my idea, and I did not want people to invent the art" (van Bruggen 19).

Bruce Nauman does not want people to come up with interpretations which are foreign to his own. The distrust Nauman expressed in many works and comments can without a doubt be linked to some of his thoughts on the anonymity of the audience. He once remarked: "It is difficult to address yourself to an anonymous public". ${ }^{20}$ It is difficult to address an anonymous audience. Anonymity can of course be linked to the unknown and the unpredictable. But is the audience really that unknown to an artist? Literary scholar Mikhail Bakhtin pointed out that we should not understand the audience as an abstraction, but as an image of the audience in the mind of the author. A work of art, according to Bakhtin, is also created as to answer a picture, an idea in the mind of the artist on the identity of his audience. This idea can easily be made explicit in relation to the work of Bruce Nauman (Bakhtin 165).

For the words Get out of My Mind Get out of This Room (1968), repetitively shouted and whispered to the audience in one of the artist's sound installations made in the same year as Stamping in the Studio, suggest that the audience was more than an anonymous entity. The resentment expressed by the artist in words that ask, beg and command the audience 
to get out of his "head", clearly suggests a heightened sense of its presence. But what were the imagined characteristics attributed to it, characteristics that made him both push it away ("get out") and call it to order ("please pay attention")?

The sculpture, denotatively entitled A Wax Mold of the Knees of Five Famous Artists [wax impressions of the knees of five famous artists] (1966) can provide some answers to this question..$^{21}$ It is a large flat fibreglass sculpture in which the artist has made five knee imprints. Every single one of them is a sign referring to an artist kneeling in what could best be described as a kind of sculptural ground. The signs however - although described as belonging to five different artists - are alike. The markings, one could argue, show Nauman's understanding of the indexical sign - a signifier that bears a direct relation to the signified; a token of real presence - as interchangeable, empty and arbitrary. Neither of these signs - "belonging" to five different artists - are able to refer to a particular artistic idiom. Indeed, with the sculpture, Nauman hinted at the fact that thinking in terms of representation was in decline. He also seemed to suggest that the audience could no longer differentiate several artistic stances. The idea was positioned in relation to sculpture. But the work can also be linked - due to the horizontal nature of the sculpture, combined with the reference to physical and bodily activity (kneeling) - to the paintingact of Jackson Pollock (1912-1956) and thus to expressionistic and representational thinking in painting. Both painterly and sculptural idioms could no longer represent a particular artistic position and an intentional mode. The artist again informed us of his intent: "To go and look at it was to try and think whether you liked to look at it, or just how involved you were in looking at art in general; that was not quite enough though, you had to know these other things too".22

"You had to know these other things too", reveals Nauman's desire to signify intentionally. But what is there to know? Reading the title can only bring about the nagging feeling that the five different artists will always remain alike and absent due to the empty and undistinguishable nature of the mark "they" left behind. But Nauman's comment also reveals his mistrust as to the ability or even the willingness of his audience to see the work in close proximity to his intentions. However, if he mistrusted the audience, it is not because it is present - an artist obviously needs an audience. Moreover, "there is a need to present yourself - to present yourself through your work is obviously part of being an artist", ${ }^{23}$ Nauman says, but he also continues: "I don't like to leave things open so that people feel they are in a situation they can play games with". ${ }^{24}$ With this remark the artist expresses his mistrust of the authorial voice of the audience. The mistrust seems to come from the idea that this audience could possibly misunderstand him or even narcissistically embody his work, thus jeopardizing his personal desire for presence, the representation of his ideas, feelings and convictions. He stated: "You work alone in the studio, and then the work goes out into a public situation. How do people deal with that?" 25

So, Nauman made sure we would be able to deal with what he did. In Stamping in the Studio , his repetitious stamping claims first stage, it becomes a soundscape and lodges itself over time as an echo in the ear, body and mind of the viewer. Reproductively pounding, almost as in a military march, it ruptures the screen, and intensifies our perception of his activity. In fact showing us - via the eye and ear - an intentional subject, persisting in his activity, getting tired, slowing down, moving faster... If anything, it positions us as what Bakhtin called a "superaddressee", a kind of witness whose responsive understanding is presumed (Bakhtin 126). And Nauman does take us up to a point of which he is sure that 
understanding is involved: "There has to be a certain sympathetic response in someone who is watching you. It is a kind of body response, they feel that foot and that tension". ${ }^{26}$

But what are we witnessing? Isn't Nauman saying I am here, but also recording it as proof of his existence as an intentional, conscious and self-aware subject at the site of creation, the studio? Telling us that what is behind the screen, in the studio, is more than an unconscious agency directing the artist at the site of creation. Showing us that his creative activity is determined by control, attention, persistence and conscious decision. But also making it - almost in an absurd way - clear that to present oneself as an artist, to expose one's work to the outside world, to an unknown audience brings about enormous anxiety. The duration of the performance then, filled and structured by a subject that refuses to be passive or lose control, can also be experienced as that of a subject that refuses to be absorbed by an unknown other: Nauman keeps moving, keeps controlling himself; even if the desire for permanent control is an absurd and even impossible - due to exhaustion, failure... - one.

The pace of time, filled and structured by rhythmic and controlled pounding steps, but also the excessive control and the visible frustration and anger emanating from the failure of staying in control all seem to point in the direction of a representation and communication debacle between artist and audience. We are left with impressions both of anxiety - a feeling that Nauman indeed wanted to represent because it mirrored how he felt at the time, not knowing how to proceed as an artist now that traditional routes such as painting and sculpture had become artistically impossible - and severe self-control emanating from Nauman's doubt as to the abilities of his audience to "understand" what he was conveying as well as to its intentions. The choice then, for working with video, for videotaping himself while performing and not performing live for an audience, also becomes clearer. It speaks of Nauman's preoccupation with the proximity of the audience in the creative act. The audience, one could say, is literally in his head. It is also something that he is wary of, something that has to be kept at a distance. Using video thus enabled him to comment upon - via an extreme self-control - the presence of the audience in the creative act, as well as him keeping the audience at a distance. With his choice for video, Nauman also aimed at a more private, a more individual encounter with members of the audience, as if to achieve a maximum and measured impact from one psyche - his - upon another: "Video is a much more 'private' kind of communication. Generally, it's what one person does. You sit and have contact with a television set, as opposed to film, where generally a lot of people go and the image is very large; it's more of a common experience". ${ }^{27}$

Working with repetition and duration gave the artist the possibility to lodge - stamp repetitively certain ideas and feelings in the experience of the performance. More than in a live performance, it offered him the chance to control the mind and perception of his audience and to make sure - as much as possible - that the desired effects and artistic goals would be met. It seems that in the face of the viewing other, the "act" art can only act out its own dependency upon this other and testify about his co-authoring, but also devouring "understanding". The latter however was exactly what the artist wanted to talk about and what he - both as person, artist and author - did not desire: "My work comes out of being frustrated about the human condition and how people refuse to understand other people". ${ }^{28}$ 


\section{BIBLIOGRAPHY}

Alberro, Alexander (ed.). Two-Way Mirror Power - Selected Writings by Dan Graham on His Art.

Cambridge Massachusetts, London England: The MIT Press, 1999.

Bakhtin, Mikhaïl M. Speech Genres \& Other Late Essays. Caryl Emerson and Michael Holquist (eds.). Austin: U of Texas P, 1986.

Crichton, Michael. Jasper Johns. New York: Harry N. Abrams, Inc., Publishers \& Whitney Museum of American Art, 1977.

Fischer-Lichte, Erika. Theater als Modell für eine performative Kultur - Zum performative turn in der europäischen Kultur des 20. Jahrhunderts. Universität des Saarlandes: Saarbrücken, 2000.

Foster, Hal. The Return of the Real - The Avant-Garde at the End of the Century. Cambridge, Massachusetts, London, England: The MIT Press, 1996.

Jones, Caroline A. Machine in the Studio - Constructing the Postwar American Artist. Chicago: The U of Chicago P, 1996.

Kraynak, Janet (ed.). Please Pay Attention Please: Bruce Nauman's Words - Writings and Interviews. Cambridge Massachusetts, London England: The MIT Press, 2003.

Lippard, Lucy R. Six Years: The Dematerialization of the Art Object from 1966 to 1972. Berkeley and Los Angeles: U of California P, 1997.

Morgan, Robert C. (ed.). Bruce Nauman. Baltimore \& London: PAJ Book, Johns Hopkins UP, 2002.

Moure, Gloria (ed.). Vito Acconci - Writings, Works, Projects. Barcelona: Ediciones Poligrafa, 2001.

Sayre, Henry M. The Object of Performance - The American Avant-garde since 1970. Chicago and London: The U of Chicago P, 1989.

Spielmann, Yvonne. Video - The Reflexive Medium. Cambridge, Massachusetts, London, England: The MIT Press, 2008.

Van Bruggen, Coosje. Bruce Nauman. New York: Rizzoli, 1988.

Von Hantelmann, Dorothea. „Inszenierungen des performativen in der zeitgenössischen Kunst“, Paragrana - Internationale Zeitschrift für Historische Anthropologie. Akademie Verlag, Band 10, 2001.

Wallace, Ian \& Russel Keziere. “Bruce Nauman Interviewed”. Vanguard 8.1 (February 1979).

\section{NOTES}

1. Bruce Nauman interviewed by Willoughby Sharp. First published as Willoughby Sharp, "Nauman Interview", Arts Magazine 44 (March 1970): 22-27. Quote taken from a reprint in Janet Kraynak (ed.), Please Pay Attention Please: Bruce Nauman's Words - Writings and Interviews, Cambridge Massachusetts, London England: The MIT Press, 2003, 113.

2. Video details: Stamping in the Studio (1968), 62 minutes, black and white, sound.

3. See for example Playing a Note on the Violin While I Walk around the Studio (1967-1968), $10 \mathrm{~min}$, black and white, sound, and Bouncing Two Balls between the Floor and Ceiling with Changing Rhythms (1976-1968), 10 min., black and white, sound. 
4. A thorough analysis of the artistic preoccupation with the studio after World War II can be found in Caroline A. Jones, Machine in the Studio - Constructing the postwar American artist, Chicago: The U of Chicago P, 1996.

5. A good account and analysis of these dematerialization tendencies can be found in Lucy R. Lippard, Six Years: The Dematerialization of the Art Object from 1966 to 1972, Berkeley and Los Angeles: U of California P, 1997.

6. Nauman did not own the video equipment himself. It was provided for by Nauman's art dealer Leo Castelli who offered it to several of the artists he represented (amongst them Richard Serra and Keith Sonnier). See Chris Dercon, Keep Taking It Apart, 1986, in Kraynak (ed.), 311. The quote comes from an interview recorded on July $12^{\text {th }} 1986$ at the Videowochen im Wenkpark, near Basel. It was first published in Kraynak (ed.).

7. Michele de Angelus, Interview with Bruce Nauman, 1980, in Kraynak (ed.), 246. The interview was never published until Janet Kraynak decided to include it in her book in 2003.

8. Video details: Art Make-Up (1967), 4.36 minutes, color.

9. Jan Butterfield, "Bruce Nauman: The center of yourself", 1975, in Kraynak (ed.), 180. Originally published in Arts Magazine 49 (February 1975): 53-55.

10. Lorraine Sciarra, "Bruce Nauman, Interview”, 1972, in Kraynak (ed.), 166. The interview was never published until Janet Kraynak decided to include it in her book in 2003.

11. Michele de Angelus, Interview with Bruce Nauman, 1980, in Kraynak (ed.), 247.

12. Willoughby Sharp, "Interview with Bruce Nauman", 1971, in Kraynak (ed.), 142. First published in Avalanche 2 (Winter 1971): 22-31.

13. Robert C. Morgan, "Interview with Bruce Nauman”, 1983, in Robert C. Morgan (ed.), Bruce Nauman, Baltimore \& London: PAJ Book, Johns Hopkins UP, 2002, 265.

14. Willoughby Sharp, "Interview with Bruce Nauman", 1971. Quote taken from a reprint in Kraynak (ed.), 113.

15. Michele de Angelus, Interview with Bruce Nauman, 1980. Quote taken from a reprint in Kraynak (ed.), 246.

16. Fischer-Lichte made a similar analysis in „Vom 'text' zur 'performance' - Der 'Performative turn' in den Kulturwissenschaften“, Kunstforum International 152 (October-December 2000): 161-163.

17. Dorothea von Hantelmann, „Inszenierungen des performativen in der zeitgenössischen Kunst", Paragrana - Internationale Zeitschrift für Historische Anthropologie, Akademie Verlag, Band 10, 2001, 255-261.

18. For a thorough analysis of Johns' exploration of the arbitrariness of the sign, see Hal Foster, The Return of the Real - The Avant-Garde at the End of the Century, Cambridge, Massachusetts, London, England: The MIT Press, 1996, 77-78. Michael Crichton, Jasper Johns, New York: Harry N. Abrams, Inc., Publishers \& Whitney Museum of American Art, 1977, 71-97.

19. Artwork details: Please Pay Attention Please (1973), collage and letraset, 69 x $69 \mathrm{~cm}$.

20. Christopher Cordes, "Talking with Bruce Nauman: An Interview", in Kraynak (ed.), 350. Originally published in John Yau, (ed.), Bruce Nauman: Prints 1970-1989, A Catalogue Raisonné, New York: Castelli Graphics \& Monk Gallery, Chicago: Donald Young Gallery, 1989.

21. Artwork details: A Wax Mold of the Knees of Five Famous Artists [wax impressions of the knees of five famous artists] (1966), fibreglass, polyester resin, 40.5 x $215 \times 7.5 \mathrm{~cm}$.

22. Bruce Nauman interviewed by Joe Raffaele. First published as Raffaele J., "The way-out west: interviews with four San Francisco artists", ARTnews, Summer 1967: 39-40 \& 75-76. Quote taken from a reprint in Kraynak (ed.), 106.

23. Joan Simon, "Breaking the silence: An Interview with Bruce Nauman", in Kraynak (ed.), 326. First published in Art in America 76 (September 1988): 140-149, 203.

24. Jan Butterfield, "Bruce Nauman: The center of yourself", 1975. Quote taken from a reprint in Kraynak (ed.), 182. 
25. Chris Dercon, Keep Taking It Apart, 1986, in Kraynak (ed.), 309.

26. Willoughby Sharp, "Interview with Bruce Nauman”, 1971, in Kraynak (ed.), 148.

27. Chris Dercon, Keep Taking It Apart, 1986, in Kraynak (ed.), 309.

28. Joan Simon, Four Artists: Robert Ryman, Eva Hesse, Bruce Nauman, Susan Rothenberg, a film by Michael Blackwood productions, Inc., New York, 1987, in Morgan (ed.), 171.

\section{ABSTRACTS}

In 1965, Sony Corporation launched the first portable video camera, the so-called Sony Portapak. This new, quite inexpensive and user-friendly technology, quickly found its way into artists' hands. Even the rather poor, "milky" character of the resulting video images did not temper artistic interest in this newfound medium. The reasons for this interest are varied. But one of them is surely the fact that it offered the possibility to work with and also "mold" time and to make duration and instances of time - for the first time in the history of the visual arts tangible. One of the pioneers that used the Portapak in order to explore amongst others the fragmentation and flow of time, endlessness and several psychological components related to a heightened awareness of having to fill time, of having to do something with the time on one's hands, was the internationally acclaimed American artist Bruce Nauman. In 1968 and 1969, the artist experimented with time by recording - with the help of a stationary Portapak, sometimes turned upside down to make time and sound more prominent - several physical actions such as running, pacing, balancing, throwing, catching a ball... Nauman drew inspiration for these performances from Stockhausen, Beckett, Reich, Monk... He however situated them in the artist's studio, bringing multiple layers of meaning into play. The article considers Nauman's choice for the time-based video medium, his use of time and the multiple meanings that can be given to his delimited actions and his desire for endlessness as well as his precarious and controlled endeavor of structuring time. The main analytical focus is the relation between Nauman and his audience and specifically the impact of Nauman's opinions on having an audience.

C'est en 1965 que Sony conçut la première caméra vidéo portable, la Sony Portapak. Cette nouvelle invention, facile d'utilisation et d'un prix abordable, suscita assez vite l'intérêt des artistes, malgré la qualité un peu “douteuse” des premières images vidéo. Cet intérêt a plusieurs causes. L'une des principales fut sans nul doute la possibilité offerte aux artistes de travailler et de "façonner" le temps, de rendre la notion de durée tangible, et ce pour la première fois dans l'histoire de l'art. Bruce Nauman, artiste américain de renommée internationale, fut l'un des premiers à utiliser la Portapak pour explorer la fragmentation et l'écoulement du temps, les phénomènes de répétition et les effets psychologiques induits par la conscience accrue que nous devons occuper le temps dont nous disposons. En 1968 et 1969, pour explorer le concept de temps, l'artiste se filma en train d'exécuter différentes actions comme courir, marcher, se balancer, lancer et attraper une balle... Il réalisa ces enregistrements à l'aide d'une caméra Portapak fixe, qu'il suspendit parfois à l'envers, afin d'accentuer les effets sonores et l'expérience $\mathrm{du}$ temps. Ces performances furent inspirées à Nauman par l'œuvre de Stockhausen, Beckett, Reich, Monk... Cependant, Nauman choisit de les réaliser dans son studio, afin d'en démultiplier les effets de sens. Dans cet article, nous nous intéresserons à l'usage que Nauman fait de la vidéo comme média enregistrant le passage du temps. Nous analyserons également la manière dont il exploite la temporalité dans ses œuvres, le sens que prennent ses actions circonscrites dans le 
temps, son désir d'infinitude, ainsi que ses tentatives précaires et contrôlées pour structurer le temps. Notre objet d'étude principal sera la relation entre l'artiste et son public, et plus précisément la façon dont Nauman concevait le fait même d'avoir un public.

\section{INDEX}

Mots-clés: art vidéo, infinitude, spectateur, performance, anxiété

Keywords: video art, endlessness, viewer, performance, anxiety

\section{AUTHORS}

\section{PATRICK VAN ROSSEM}

Dr. Patrick Van Rossem is Associate Professor in Modern and Contemporary Art at the History and Art History Department, section Modern and Contemporary Art, of Utrecht University (The Netherlands). He was Assistant Professor in Art History at Ghent University (Belgium) from 2006 until 2008. Van Rossem earned his Ph.D. in Art History and authored Creation and Desire in the Encounter with the Audience: A Study on Bruce Nauman's, Martin Kippenberger's and Anne-Mie Van Kerckhoven's Self-Presentation (Ghent University). His research interests include the performative turn in the visual arts, artist-audience relations from the 1960 s onwards, $20^{\text {th }}$-century discourses on painting and embodiment. 